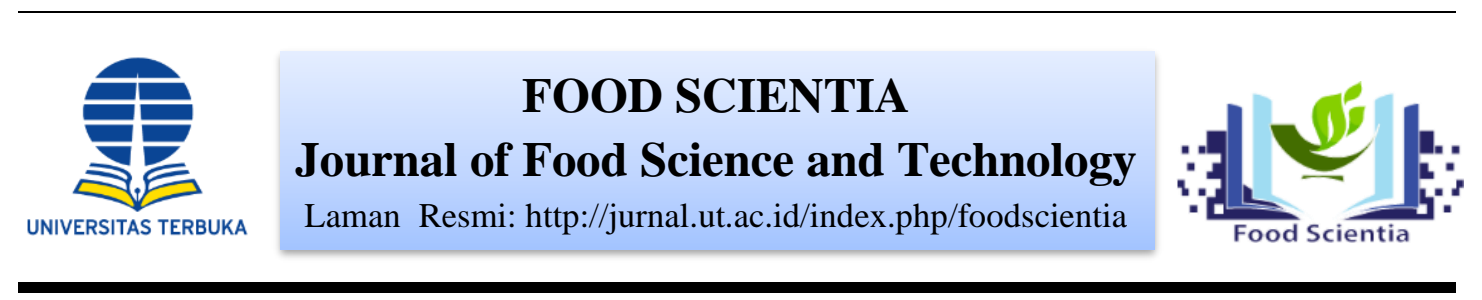

\title{
ANALISIS KANDUNGAN LOGAM BERAT TIMBAL (Pb) PADA PRODUK OLAHAN SUSU
}

\author{
Analysis of Lead (Pb) Content on Dairy Products \\ Evi Mardiastuty Silalahi ${ }^{1}$, Endang Purwanti ${ }^{2}$ \\ ${ }^{1,2}$ Laboratorium Kesehatan Masyarakat Veteriner (Kesmavet) \\ Pusat Pelayanan Kesehatan Hewan dan Peternakan Provinsi DKI Jakarta \\ Jalan Raya Bambu Apus Cipayung Jakarta Timur, 13840, Indonesia \\ e-mail: evi.silalahi75@gmail.com
}

DOI: $10.33830 /$ fsj.v1i1.1455.2021

Diterima: 15 April 2021, Diperbaiki: 4 Mei 2021, Disetujui: 10 Juni 2021

\begin{abstract}
Lead $(P b)$ is a toxic substance that easily accumulates in human organs and can cause health problems such as anemia, impaired kidney function and impaired nerve, brain and skin tissue system. Analysis of the heavy metal content of Lead $(\mathrm{Pb})$ in dairy products is needed to determine the feasibility of consuming these products. This research was conducted from June until August 2020 at Laboratory. The objective of this research was to determine lead content in dairy products in the form of pasteurized milk, cheese, butter and yoghurt using Inductively Couple Plasma-Mass Spectrometry (ICP-MS) method. Samples were prepared using the wet destruction method with $\mathrm{HNO}_{3} 65 \%$ ultrapure $\mathrm{H}_{2} \mathrm{O}_{2} \quad 30 \%$ ultrapure and $\mathrm{HCl}$ ultrapure. The contents of lead obtained from the research were, for the first batch: pasteurized milk <0,001 mg/kg, cheese <0,001 mg/kg, butter 0,004 $\mathrm{mg} / \mathrm{kg}$ and yoghurt $<0,001 \mathrm{mg} / \mathrm{kg}$. For the second batch of the pasteurized milk, the lead contents were: pasteurized milk $0,020 \mathrm{mg} / \mathrm{kg}$, cheese $0,011 \mathrm{mg} / \mathrm{kg}$, butter $0,006 \mathrm{mg} / \mathrm{kg}$ and yoghurt 0,025 $\mathrm{mg} / \mathrm{kg}$. The lead contents for third batch were: pasteurized milk <0,001 mg/kg, cheese 0,008 $\mathrm{mg} / \mathrm{kg}$, butter $0,004 \mathrm{mg} / \mathrm{kg}$, yoghurt $<0,001 \mathrm{mg} / \mathrm{kg}$. The results of this study were then compared Maximum Limit of Heavy Metal in Food according to SNI 7387 : 2009 and BPOM Regulation No. 23 year 2017.
\end{abstract}

Keywords: lead (Pb), dairy products, maximum limit of heavy metal in food

\begin{abstract}
ABSTRAK
Timbal $(\mathrm{Pb})$ adalah bahan toksik yang mudah terakumulasi dalam organ manusia dan dapat mengakibatkan gangguan kesehatan berupa anemia, gangguan fungsi ginjal, gangguan sistem syaraf, otak, dan kulit. Analisis kandungan logam berat Pb pada produk olahan susu diperlukan untuk mengetahui kelayakan konsumsi produk tersebut. Penelitian ini dilakukan pada bulan Juni-Agustus 2020 di Laboratorium. Tujuan penelitian ini untuk mengetahui kadar kontaminan logam berat Pb pada produk olahan susu yang berupa susu pasteurisasi, keju, mentega, dan yoghurt dengan metode Inductively Couple Plasma-Mass Spectrometry
\end{abstract}


(ICP-MS). Preparasi sampel menggunakan metode destruksi basah dengan pelarut $\mathrm{HNO}_{3}$ $65 \%$ ultrapur, $\mathrm{H}_{2} \mathrm{O}_{2} 30 \%$ ultrapur dan $\mathrm{HCl}$ ultrapur. Kadar logam berat $\mathrm{Pb}$ yang diperoleh dari hasil penelitian yaitu produksi pertama pada sampel susu pasteurisasi $<0,001 \mathrm{mg} / \mathrm{kg}$, $\mathrm{keju}<0,001 \mathrm{mg} / \mathrm{kg}$, mentega 0,004 mg/kg, yoghurt <0,001 mg/kg, produksi kedua pada sampel susu pasteurisasi sebesar 0,020 mg/kg, keju 0,011 mg/kg, mentega 0,006 mg/kg, yoghurt 0,025 mg/kg, dan produksi ketiga pada sampel susu pasteurisasi < 0,001 mg/kg, keju 0,008 mg/kg, mentega <0,001 mg/kg, yoghurt <0,001 mg/kg. Hasil penelitian tersebut dibandingkan dengan Batas Maksimum Cemaran Logam Berat dalam Pangan menurut SNI 7387:2009 dan Peraturan BPOM No 23 Tahun 2017.

Kata kunci: timbal (Pb), produk olahan susu, batas cemaran logam berat

\section{PENDAHULUAN}

Timbal $(\mathrm{Pb})$ adalah jenis logam berat yang bersifat toksik yang ketika masuk ke dalam tubuh akan terikat dengan protein sehingga hanya sedikit yang dieksresikan (Anindhita et al., 2014). Logam timbal dapat masuk ke dalam makanan seperti produk olahan susu melalui alat-alat pengolahan produksi hasil peternakan yang terbuat dari logam sehingga dapat terjadi migrasi logam timbal ke dalam produk hasil peternakan tersebut atau kontaminasi bahan baku saat pengolahan produk olahan susu. Akumulasi logam berat timbal di dalam tubuh manusia dapat menyebabkan gangguan pada susunan syaraf, fungsi ginjal, dan sistem reproduksi.

Inductively Couple Plasma-Mass Spectrometry (ICP-MS) adalah sebuah teknik analisis yang digunakan untuk mendeteksi trace metal dalam sampel. Teknik analisis ini sangat sensitif digunakan untuk menentukan kadar logam berat timbal dalam produk olahan susu karena unsur logam berat tersebut relatif kecil. Metode ini memiliki keuntungan yaitu dapat menganalisis beberapa unsur secara bersamaan, sensitivitas tinggi, dan memiliki limit deteksi yang rendah.

Prinsip kerja alat ini adalah dengan mengukur intensitas energi yang dipancarkan oleh unsur-unsur yang mengalami perubahan tingkat energi atom. Larutan sampel dihisap dan dialirkan melalui tabung kapiler ke nebulizer. Nebulizer akan mengubah larutan sampel menjadi bentuk aerosol. Kemudian aerosol yang terseleksi dibawa oleh gas argon ke plasma yaitu nyala listrik yang sangat panas dengan suhu sekitar $7500^{\circ} \mathrm{K}$. Selama di plasma partikel aerosol terdesolvasi dan molekul sampel terdisosiasi menjadi atom gas, kemudian tereksitasi dan terionisasi. Ion-ion tersebut masuk ke kuadrupol massa dan dipisahkan oleh mass analyzer berdasarkan massa. Skema alat dapat dilihat pada Gambar 1. 


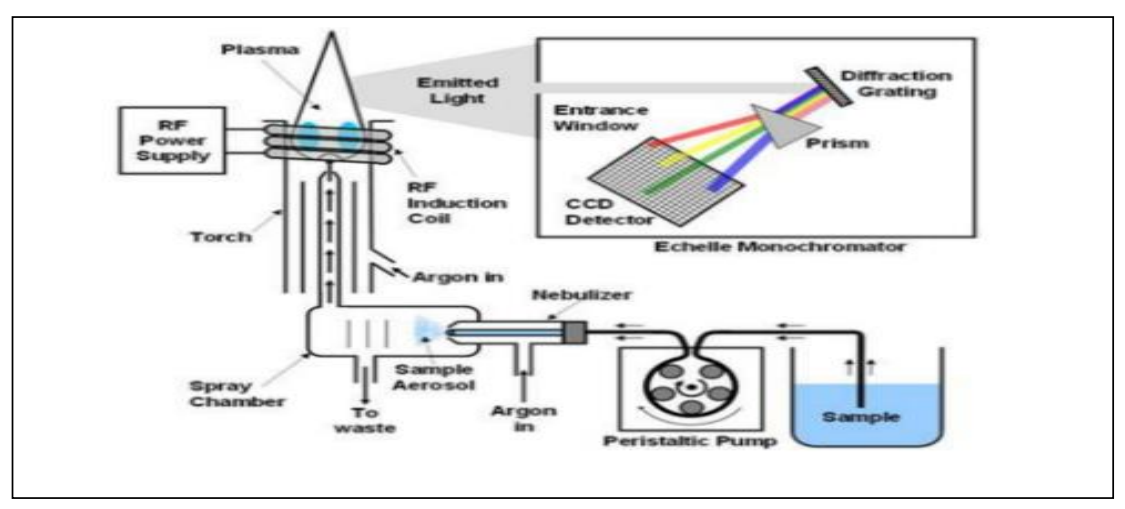

Gambar 1. Skema alat ICP-MS (Siaka, 2015)

Salah satu hal yang perlu dilakukan dalam pengendalian dan pemantauan cemaran logam timbal adalah dengan menganalisis kadar logam timbal pada produk olahan susu yang berupa susu pasteurisasi, keju, mentega, dan yoghurt. Hasil analisis tersebut dibandingkan dengan Batas Maksimum Cemaran Logam Berat dalam Pangan menurut SNI 7387:2009 dan Peraturan BPOM No 23 Tahun 2017 untuk mengetahui kelayakan konsumsi produk tersebut. (Badan Pengawas Obat Dan Makanan Republik Indonesia, 2017)

\section{METODE}

\section{Tempat dan Waktu}

Penelitian ini dilakukan di Jakarta pada bulan Juni sampai dengan Agustus 2020. Analisis sampel logam berat timbal dilakukan di Laboratorium. Pusat Pelayanan Kesehatan Hewan dan Peternakan Provinsi DKI Jakarta.

\section{Alat dan Bahan}

Alat yang digunakan adalah pinset, spatula, vessel, neraca analitik Denver, Microwave digestion MARS6 CEM, Bottle top dispenser Brand, botol sampel PFA (Perfluoro Alkoxy), labu ukur PFA, pipet tetes PP (Polypropilene), Millipore ultrapure water system, lemari asam, refrigerator, freezer, pipet mikro, tips mikro pipet, syringe filter, disc filter $0,2 \mu \mathrm{m}$, tabung sentrifus PP, dan ICP-MS Bruker Aurora M90.

Bahan yang digunakan adalah $\mathrm{HNO}_{3}$ ultrex 65\% JT Baker, $\mathrm{HCl}$ grade ultra $30 \%$ Merck, $\mathrm{H}_{2} \mathrm{O}_{2}$ grade ultra 30\% Merck, ultrapure water, larutan standar $\mathrm{Pb}$ grade ICP Merck konsentrasi 1000 mg/L, Tuning solution Agilent konsenrasi 10 mg/L, gas 
argon high purity, gas hidrogen high purity, sampel produk olahan susu (susu pasteurisasi, keju, mentega, dan yoghurt) yang diperoleh dari produksi 1, 2, dan 3 (dengan bahan baku susu sapi murni).

\section{Rancangan Percobaan}

Pada penelitian ini rancangan percobaan yang digunakan yaitu Rancangan Acak Lengkap (RAL) dengan satu faktor yaitu logam berat timbal. Faktor yang diteliti adalah kandungan logam berat timbal dalam produk olahan susu berupa susu pasteurisasi, keju, mentega, dan yoghurt. Hipotesis yang diuji dalam penelitian ini adalah produk olahan susu yang diuji bebas dari pencemaran kontaminan timbal sehingga layak untuk dikonsumsi.

\section{Tahap Penelitian}

Preparasi Sampel

Sampel dihaluskan kemudian sebanyak 0,5 gram ditimbang dalam vessel dan ditambahkan $8 \mathrm{ml} \mathrm{HNO}_{3}$ ultrex 65\% kemudian didiamkan selama 30 menit. Setelah itu ditambahkan $1 \mathrm{ml} \mathrm{H}_{2} \mathrm{O}_{2}$ grade ultra 30\% dan didiamkan selama 15 menit. vessel kemudian ditutup rapat dan dimasukkan ke dalam Microwave selama 1 jam. Setelah proses ekstraksi selesai vessel dikeluarkan dari Microwave dan dimasukkan ke dalam lemari asam, di buka tutupnya untuk menghilangkan uap nitrat. Kemudian sampel ditambahkan 0,5 $\mathrm{ml} \mathrm{HCl}$ grade ultra $30 \%$ dan diencerkan dengan ultrapure water menjadi $100 \mathrm{ml}$ di dalam labu ukur PFA. Sampel lalu disaring menggunakan syringe filter dan disc filter $0,2 \mu \mathrm{m}$ untuk menghilangkan partikel yang tidak terlarut (AOAC Official Method 2015.01 Heavy Metals in Food, 2019).

\section{Pembuatan Pelarut Standar}

Larutan $\mathrm{HNO}_{3}$ ultrex $65 \%$ sebanyak $25 \mathrm{ml}$ dipipet ke dalam labu takar PFA $500 \mathrm{ml}$ yang telah berisi ultrapure water kemudian ditambahkan 2,5 $\mathrm{ml} \mathrm{HCl}$ grade ultra 30\% dan larutan ditepatkan hingga batas menggunakan ultrapure water. 


\section{Pembuatan Larutan Standar Pb Intermediate (1000 $\mu \mathrm{g} / \mathrm{L})$}

Diambil larutan Pb grade ICP Merck konsentrasi 1000 mg/L sebanyak $50 \mu \mathrm{l}$ kedalam labu ukur PFA volume $50 \mathrm{ml}$ dan ditepatkan dengan pelarut standar dan dihomogenkan.

\section{Pembuatan Larutan Standar Pb kerja dengan 6 konsentrasi $(0,1,2,3,4,5$} $\mu \mathrm{g} / \mathrm{L})$.

Diambil larutan standar $\mathrm{Pb}$ Intermediate $(1000 \mu \mathrm{g} / \mathrm{L})$ masing - masing sebanyak $0 \mu \mathrm{L} ; 50 \mu \mathrm{L} ; 100 \mu \mathrm{L} ; 150 \mu \mathrm{L} ; 200 \mu \mathrm{L} ; 250 \mu \mathrm{L}$ ke dalam labu takar PFA 50 mL. Lalu masing - masing larutan standar ditepatkan hingga batas dengan pelarut standar lalu dihomogenkan.

\section{Pembuatan Larutan ICP - MS Tune $5 \mu \mathrm{g} / \mathrm{L}$.}

Diambil $50 \mu \mathrm{L}$ ICP - MS Tuning solution $10 \mathrm{mg} / \mathrm{L}$ dengan pipet mikro ke dalam labu ukur PFA $100 \mathrm{ml}$ dan ditambahkan pelarut standar hingga tanda batas dan dihomogenkan.

\section{Pengujian Sampel dengan alat ICP-MS}

Sampel dianalisis dengan alat ICP-MS, menggunakan $R F$ Power sebesar 1,50 $\mathrm{kW}$, aliran plasma $18 \mathrm{~L} /$ menit, laju alir nebulizer 1,25 L/menit, kecepatan pompa 7 rpm, dan waktu pengambilan setiap sampel 40 detik. Gas argon digunakan sebagai bahan bakar nyala plasma dan gas hidrogen sebagai gas pembawa dengan laju alir 80 $\mathrm{ml} / \mathrm{menit}$.

Pengecekan kondisi alat sebelum analisis dilakukan dengan mengalirkan larutan ICP - MS Tune $5 \mu \mathrm{g} / \mathrm{L}$ pada menu plasma align. Hasil analisis dibandingkan dengan standar yang ditetapkan. Jika persyaratan standar terpenuhi maka analisis sampel dapat dilanjutkan.

\section{HASIL PEMBAHASAN}

Pengukuran deret standar logam berat timbal dilakukan sebanyak 3 (tiga) kali. Hasil pengukuran deret standar logam berat timbal dapat dilihat pada Gambar 2, Grafik (a) pembacaan standar timbal pertama, (b) permbacaan standar timbal kedua 
dan (c) pembacaan standar timbal ketiga. Kurva kalibrasi standar timbal merupakan hubungan linier antara konsentrasi standar timbal (sumbu $\mathrm{x}$ ) dengan nilai count/second (sumbu y) yang diperoleh dari respon instrumen. Berdasarkan hasil tersebut diketahui bahwa semakin besar konsentrasi maka nilai count/second yang diperoleh akan semakin besar atau konsentrasi berbanding lurus dengan nilai count/second.

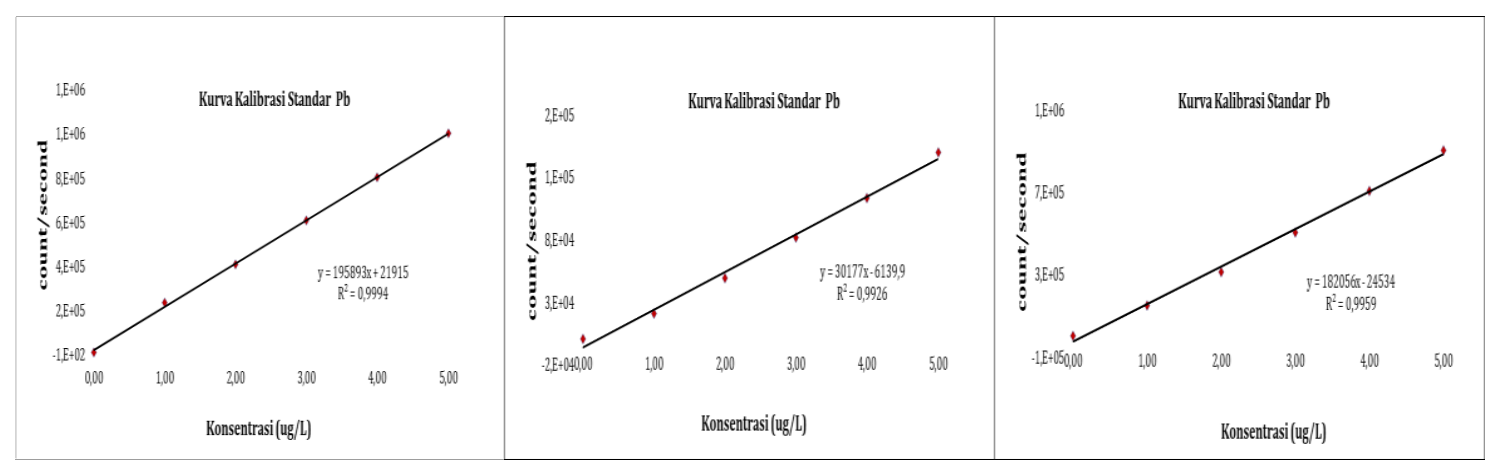

(a)

(b)

(c)

Gambar 2. Kurva Pembacaan Standar Timbal

Dilakukan perhitungan regresi linear pada deret standar logam berat timbal, perhitungan nilai SD (Standard Deviation) dan \%RSD. Nilai SD menunjukkan seberapa jauh pengulangan hasil analisis mendapatkan hasil yang sama dan RSD menunjukkan bahwa ketelitian semakin baik. Batas nilai RSD berdasarkan AOAC (Association of Official Analytical Chemist) tahun 2019 untuk senyawa dengan konsentrasi sedikit adalah $5-15 \%$ dan hasil RSD yang diperoleh untuk pengukuran standar $\mathrm{Pb}$ berkisar antara 0,12 - 2,08\%. Dapat dikatakan ketelitian pengujian menggunakan alat ICP-MS cukup baik karena nilai RSD pada pengukuran deret standar tidak ada yang melebihi $5 \%$.

Hasil analisis internal kontrol CRM (Certified Reference Material) dapat dilihat pada tabel 1: 
Tabel 1. Hasil Analisis Logam timbal ( $\mathrm{Pb})$ dalam Internal Kontrol CRM Milk Powder

\begin{tabular}{lccc}
\hline Jenis sampel & $\begin{array}{c}\text { Kadar Pb (mg/kg) } \\
\text { Hasil Analisis }\end{array}$ & $\begin{array}{c}\text { Kadar Pb (mg/kg) } \\
\text { Sertifikat }\end{array}$ & Keterangan \\
\hline $\begin{array}{lccc}\text { Milk Powder 1 } \\
\text { (Pembacaan pertama) }\end{array}$ & 0,07 & & \\
Milk Powder 2 & 0,06 & $0,08 \pm 0,03$ & Memenuhi \\
(Pembacaan kedua) & 0,08 & & \\
$\begin{array}{l}\text { Milk Powder 3 } \\
\text { (Pembacaan ketiga) }\end{array}$ & & & \\
\hline
\end{tabular}

Hasil analisis CRM dengan menggunakan metode pengujian ini sesuai dengan hasil yang tercantum pada sertifikat hal ini menunjukkan bahwa metode yang digunakan akurat dan tertelusur. Hasil analisis sampel dapat dilihat pada tabel 2 berikut :

Tabel 2. Hasil Analisis Kadar Logam Timbal (Pb) dengan ICP-MS

\begin{tabular}{lccc}
\hline & $\begin{array}{c}\text { Kadar } \mathbf{P b} \\
(\mathbf{m g} / \mathbf{k g})\end{array}$ & $\begin{array}{c}\text { Kadar } \mathbf{P b} \\
(\mathbf{m g} / \mathbf{k g})\end{array}$ & $\begin{array}{c}\text { Kadar } \mathbf{P b} \\
(\mathbf{m g} / \mathbf{k g})\end{array}$ \\
Jenis sampel & $\begin{array}{c}\text { Produksi } \\
\text { Pertama }\end{array}$ & Kroduksi & Produksi \\
& $<0,001$ & 0,02 & Ketiga \\
\hline Susu pasteurisasi & $<0,001$ & 0,01 & 0,0001 \\
Keju & 0,004 & 0,01 & $<0,001$ \\
Mentega & $<0,001$ & 0,02 & $<0,001$ \\
Yoghurt & & &
\end{tabular}

Keterangan :

Analisis dilakukan pada sampel yang diproduksi dari 3 produksi yang berbeda.

Hasil analisis logam berat timbal pada Tabel 2 menunjukkan adanya kandungan logam berat timbal diproduksi pertama pada sampel mentega sebesar $0,004 \mathrm{mg} / \mathrm{kg}$, produksi kedua pada sampel susu pasteurisasi sebesar 0,02 mg/kg, sampel keju sebesar $0,01 \mathrm{mg} / \mathrm{kg}$, sampel mentega sebesar $0,01 \mathrm{mg} / \mathrm{kg}$, sampel 
yoghurt sebesar 0,02 $\mathrm{mg} / \mathrm{kg}$, dan produksi ketiga pada sampel keju sebesar 0,01 mg/kg. Menurut persyaratan SNI 7387 : 2009 (Batas Maksimum Cemaran Logam Berat dalam Pangan) untuk batas maksimum cemaran timbal $(\mathrm{Pb})$ dalam pangan untuk kategori pangan produk susu sebesar $0,02 \mathrm{mg} / \mathrm{kg}$ (dihitung terhadap produk siap konsumsi) dan menurut Peraturan BPOM No. 23 Tahun 2017 (Batas Maksimum Cemaran Logam Berat dalam Pangan Olahan) untuk batas maksimum cemaran timbal $(\mathrm{Pb})$ dalam pangan untuk kategori pangan produk - produk susu dan analognya sebesar $0,02 \mathrm{mg} / \mathrm{kg}$ (dihitung terhadap produk siap konsumsi).

Hasil analisis kadar logam berat timbal yang diperoleh dibandingkan dengan persyaratan kedua standar tersebut terlihat bahwa kadar logam berat timbal pada sampel susu pasteurisasi dan yoghurt (produksi kedua) sama dengan dan melebihi batasan yang telah ditetapkan, sedangkan kadar logam berat timbal pada sampel mentega (produksi pertama dan kedua), dan sampel keju (produksi kedua dan ketiga) masih di bawah batasan yang telah ditetapkan. Kadar logam berat timbal untuk sampel lainnya pada (produksi pertama, kedua dan ketiga) di bawah LOD (Limit of Detection) dari alat ICP-MS yang digunakan yaitu sebesar $0,001 \mathrm{mg} / \mathrm{kg}$. Hal tersebut menunjukkan bahwa produk susu pasteurisasi dan yoghurt (Produksi kedua) tidak layak untuk dikonsumsi, produk mentega (Produksi pertama dan kedua), dan produk keju (Produksi kedua dan ketiga) masih dapat dikonsumsi, sedangkan produk olahan susu lainnya layak untuk di konsumsi.

Bagi industri pangan, menjamin keamanan produk merupakan suatu keharusan agar produk yang dihasilkan dapat memenuhi persyaratan konsumen. Untuk menghasilkan suatu produk, industri pangan melakukan serangkaian kegiatan yang sangat kompleks mulai dari penerimaan bahan baku, proses produksi sampai dengan distribusi. Pada setiap tahapan tersebut sangat mungkin terjadi kontaminasi bahaya biologis, kimia, dan fisik yang menyebabkan pangan menjadi tidak aman untuk dikonsumsi. Adapun potensi bahaya yang ditimbulkan selama produksi pangan dapat berasal dari sumber-sumber yang terlibat dalam proses, seperti bahan baku, bahan pembantu, pekerja, peralatan, ruangan, dan lingkungan industri (Nuraida, 2014) Pengendalian keamanan pangan memerlukan suatu sistem yang bersifat baku dan dapat diterima di seluruh dunia. FAO (Food and Agricultural Organization ) melalui CAC (Codex Alimentarius Commision) telah mengambil langkah untuk memberikan 
pedoman dengan mengadopsi sistem HACCP (Hazard Analysis and Critical Control Point ) sebagai satu-satunya sistem jaminan mutu yang berbasis keamanan pangan. Penerapan HACCP untuk menjamin keamanan pangan didasarkan pada prinsip pencegahan bahaya yang timbul selama proses produksi berlangsung (Nuraida, 2014).

Dengan adanya cemaran pada produk olahan susu yang berasal dari industri pangan maka diharapakan agar industri pangan menerapkan sistem penjaminan mutu yang berbasis pada keamanan pangan, agar produk pangan yang dihasilkan aman untuk dikonsumsi masyarakat.

\section{KESIMPULAN}

Dari hasil penelitian yang telah dilakukan maka diperoleh kesimpulan yaitu produk susu pasteurisasi dan yoghurt dari hasil produksi kedua tidak layak atau tidak aman untuk dikonsumsi karena mengandung kontaminan logam berat timbal melebihi batasan yang dipersyaratkan dalam SNI 7387 : 2009 dan Peraturan BPOM No 23 Tahun 2017 yaitu untuk kategori pangan produk-produk susu dan analognya sebesar 0,02 mg/kg (dihitung pada produk siap konsumsi). Produk mentega dari hasil produksi pertama dan kedua, serta produk keju dari hasil produksi kedua dan ketiga masih dapat dikonsumsi karena kandungan kontaminan logam berat timbal masih di bawah batasan yang dipersyaratkan tersebut. Produk susu pasteurisasi (produksi pertama dan kedua), keju (produksi pertama), mentega (produksi ketiga), dan yoghurt (produksi pertama dan ketiga) layak atau aman untuk dikonsumsi karena tidak ditemukan adanya kontaminan logam berat timbal dalam produk atau di bawah LOD alat ICP-MS yaitu sebesar $0,001 \mathrm{mg} / \mathrm{kg}$. Adanya kontaminasi logam timbal pada produk olahan susu menunjukkan bahwa telah terjadi pencemaran pada produk olahan tersebut.

\section{SARAN}

Banyak faktor penyebab terjadinya kontaminasi logam berat timbal pada produk olahan susu yang harus diteliti lebih lanjut. Diharapkan agar industri pangan menerapkan sistem jaminan mutu yang berbasis keamanan pangan, agar produk pangan yang dihasilkan aman untuk dikonsumsi masyarakat. Perlu dilakukan 
pengawasan, evaluasi, dan sosialisasi mengenai sistem jaminan mutu yang berbasis keamanan pangan bagi industri pangan.

\section{DAFTAR PUSTAKA}

Anindhita A., Rusmalina M., Soeprapto S., Analisis Logam Berat Timbal (Pb) Pada Ikan Lele (Clarias Sp.) Yang Dibudidayakan Di Kota Pekalongan. Hasil Peneltian Fakultas Pertanian Universitas Jenderal Soedirman

AOAC Official Method 2015.01 Heavy Metals in Food. (2019) : Inductively Coupled Plasma - Mass Spectrometry. Bab 9 halaman $69-76$

BSN. SNI 7387 : 2009. Batas Maksimum Cemaran Logam Berat Dalam Makanan.

FDA Elemental Analysis Manual For Food. (2015). Inductively Coupled Plasma Mass Spectrometric Determination of Arsenic (As), Cadmium (Cd), Chromium $(\mathrm{Cr})$, Lead $(\mathrm{Pb})$, Mercury $(\mathrm{Hg})$ And Other Elements in Food Using Microwave Assisted Digestion.

Nuraida, L . (2014). Keamanan Pangan, Jakarta Universitas Terbuka

Badan Pengawas Obat dan Makanan Republik Indonesia. Peraturan Kepala Badan POM No.23 tahun 2017 tentang Pendaftaran Pangan Olahan. Jakarta :Badan Pengawas Obat Dan Makanan Republik Indonesia

Siaka, IM. 2015. Inductively Couple Plasma - Mass Spectrometry (ICP-MS). 